\title{
COASTAL CLIFF INSTABILITY, A CASE STUDY FROM THE UK
}

\author{
Saroglou C. ${ }^{1}$ and Alexandrou D. ${ }^{2}$ \\ ${ }^{1}$ Department of Geotechnics, School of Civil Engineering, National Technical University of \\ Athens, Athens, Greece, saroglou@central.ntua.gr \\ ${ }^{2}$ AECOM, London, United Kingdom, alexandroudimitrios@gmail.com
}

\begin{abstract}
The present paper presents the conceptual ground model for coastal cliff retreat and instability. Cliff instability has been intensified due to climate change in the last years, especially by sea level change and high windstorms. A case study of cliff instability in the $S W$ coast in the UK is presented. The stability of the cliffs is primarily controlled by the presence of tensile cracks parallel to the cliff face and intersecting fractures as well as undercutting of cliff base due to wave action. The cliff instability mechanisms were identified for different locations along the shoreline and the cliffs were classified according to the cliff behaviour unit approach.

Keywords: Coast, slope stability, chalk, erosion.
\end{abstract}

\section{Пєрі́ $\eta \psi \eta$}

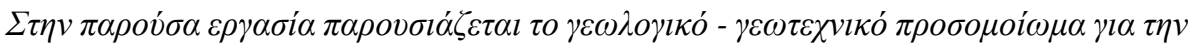

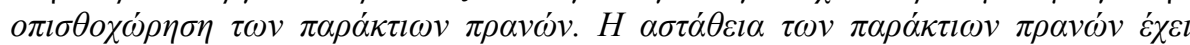

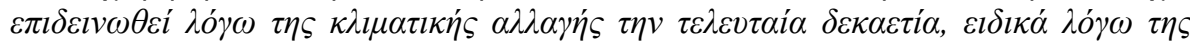

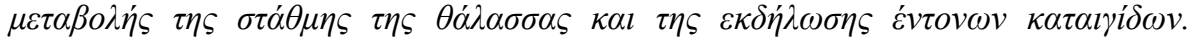

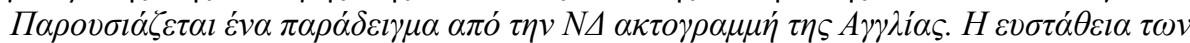

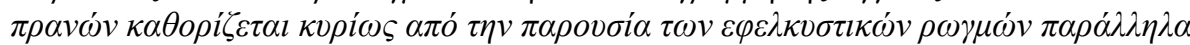

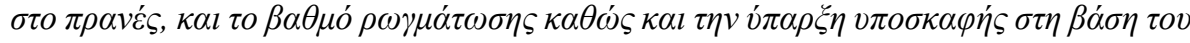

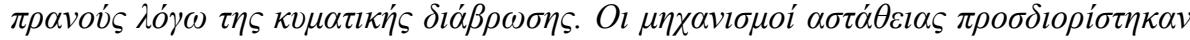

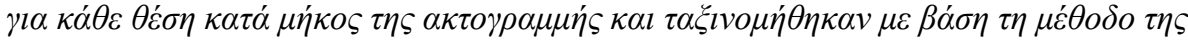

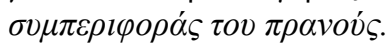

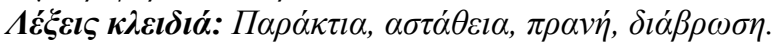

\section{Introduction}

Coastal erosion is a significant geological phenomenon with enormous economical and social impacts for the areas that are subjected to this process. Small and Nicholls (2003) estimated that almost one quarter of the global population lives in near shore areas and Emery and Kuhn (1982) stated that approximately $80 \%$ of the world's shoreline located on rock formations. It is well studied that from the ancient times people use to develop residential and commercial areas close to the coastline. In the United Kingdom the problem of the shoreline retreat is of concern since the late 18 th and early 19th centuries, when the first defence structures appeared. Coastal erosion is defined as the removal and the loss of material from the coast due to wave and tidal energy (BGS, 2012).

Cliff instability of a coastal cliff comprises mass movements and slope failures that might result in the heave and deposition of debris on the beach and foreshore. It should be noted that some large scale landslides are extended to a significant distance inland and offshore, and below the beach level. 
Cliff instability can be summarized in a four-stage process according to Moore et al. (2010). These four stages can be considered as one erosion cycle which involves the detachment of the particles or blocks of the failed material, their transport through the cliff system, their deposition on the foreshore area and finally their removal by wave and tidal action (Moore et al., 2010).

Cliff recession is the landward retreat of the cliff profile, from cliff toe to cliff top, which is an outcome of cliff instabilities and erosion processes. The cliff recession is a non-linear and nonuniform process in space and time and is affected by a variety of factors that regulate the rates of detachment and transport (Moore et al., 2010). The recession rates, the retreat mode and the erosion mechanism are site specific (Naylor et al., 2010), depending on the geological variation in both vertical and horizontal direction (Castedo et al., 2012; Rosser et al., 2013), the changes in the pore water pressure conditions (Rosser et al., 2013) and seepage erosion (Lee and Clark, 2002), the rock strength (Sunamura, 1982; Collins and Sitar, 2008), the structure of the material (Allison and Kimber, 1998), the orientation and the potency of the environmental forces (Adams et al., 2002), the presence of beach sediments which act as a barrier (Limber and Murray, 2011) and the climate (Castedo et al., 2012).

\section{Conceptual ground model}

\subsection{General}

In the case of cliff instability and cliff recession, the conceptual ground model should include the concept of time scale and summarise the controlling factors of cliff instability and cliff recession processes. The concept of time scale is significant as it describes the evolution of the phenomenon. The model should be able to capture and predict vertical and lateral variations of the analysed formation in the future, taking into account its behaviour and form of failure in the past.

The conceptual ground model should describe the range of processes that can modify the geotechnical properties of the initial rock type (weathering, tectonic activity, erosion, solution, sea level changes, etc) and the effects on the geotechnical parameters. A conceptual ground model for the description of the cliff erosion processes is illustrated in Figure 1 (Castedo et al., 2012).

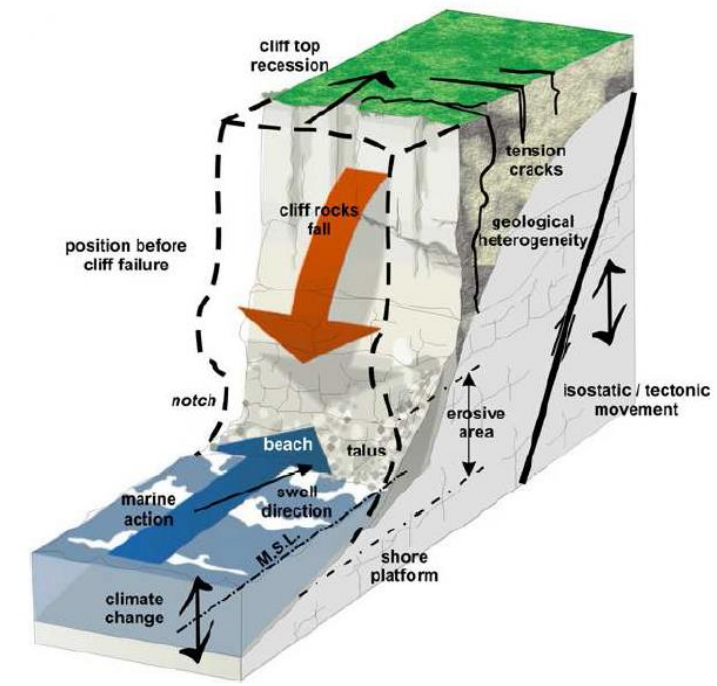

Figure 1 - Conceptual ground model of coastal cliff unit, representing geomorphological and erosive processes. 


\subsection{Factors influencing the coastal cliff system}

The most significant factors that influence the coastal cliff system are illustrated in Table 1 (modified after Carpenter, 2014).

It has been divided in different sub-systems and correlated with the associated factors. This is not always possible due to the complexity of the coastal cliff system, the interactions and overlapping between the different sub-systems.

Table 1 - Main sub-systems and factors influencing the coastal cliff system.

\begin{tabular}{|c|c|c|c|}
\hline Sub-System & Role/Description & $\begin{array}{c}\text { Cliff Features } \\
\text { Under } \\
\text { Influence }\end{array}$ & Associated Factors \\
\hline $\begin{array}{l}\text { Geotechnical, } \\
\text { Geological, } \\
\text { Hydrogeological }\end{array}$ & $\begin{array}{l}\text { The internal controls } \\
\text { of the cliff system } \\
\text { which ultimately } \\
\text { determine its shear } \\
\text { strength }\end{array}$ & $\begin{array}{l}\text { Cliff face and } \\
\text { talus }\end{array}$ & $\begin{array}{l}\text { - Geology, lithology, structure } \\
\text { - Groundwater, pore water } \\
\text { pressure, seepage erosion } \\
\text { - Cliff geometry } \\
\text { - Strain softening, progressive } \\
\text { failure }\end{array}$ \\
\hline Sub-Aerial & $\begin{array}{l}\text { Processes acting on } \\
\text { the earth's surface }\end{array}$ & $\begin{array}{l}\text { Cliff face and } \\
\text { talus }\end{array}$ & $\begin{array}{l}\text { - Vegetation } \\
\text { - Weathering }\end{array}$ \\
\hline $\begin{array}{l}\text { Coastal and } \\
\text { Marine }\end{array}$ & $\begin{array}{l}\text { Processes acting on } \\
\text { the earth's surface }\end{array}$ & $\begin{array}{l}\text { Shore platform, } \\
\text { beach } \\
\text { and talus }\end{array}$ & $\begin{array}{l}\text { - Wave energy } \\
\text { - Presence of fronting beach } \\
\text { - Shore platform }\end{array}$ \\
\hline $\begin{array}{l}\text { Meteorological } \\
\text { and Climatic }\end{array}$ & $\begin{array}{l}\text { Atmospheric drivers } \\
\text { and potential changes } \\
\text { to the system as a } \\
\text { result of climate } \\
\text { changes }\end{array}$ & $\begin{array}{l}\text { Indirect } \\
\text { influence } \\
\text { through other } \\
\text { subsystems }\end{array}$ & $\begin{array}{l}\text { - Rainfall } \\
\text { - Sea level, tide level } \\
\text { - Storms and storm } \\
\text { surges }\end{array}$ \\
\hline Human & $\begin{array}{l}\text { Anthropogenic } \\
\text { intervention of the } \\
\text { cliff system }\end{array}$ & $\begin{array}{l}\text { Cliff face and } \\
\text { beach }\end{array}$ & $\begin{array}{l}\text { - Defence structures } \\
\text { - Other activities }\end{array}$ \\
\hline
\end{tabular}

\subsection{Process - Response systems}

A number of processes-response systems exist in literature e.g. from Lee et al. (2001) and Castedo et al. (2012). These conceptual models have been developed considering a series of different factors and interactions, trying to capture the natural variability of the cliff system. The factors in both cases have been broken down into key components and key processes in order to demonstrate a holistic approach to the problem.

A processes-response system is considered by Lee and Clark (2002) as the base for the assessment of a "Cliff Behaviour Unit" which will comprise all the controlling factors and will provide a constant feedback for the majority of the processes. A limitation of these theories most of the times is the lack of geographical definition. The geographical position of the study area determines the leading mechanisms of the weather, which will be different in a tropical climate in respect to a temperate one. Furthermore, the style of failure is also difficult to be taken into account. The model from Castedo et al. (2012) tries to comprise a limit equilibrium approach. However, the complexity of these systems cannot be analysed from general approaches but only with site specific analysis. It usually leads to oversimplifications in the geometry, geology or style of failure.

One of the key features in these systems, which require constant feedback, is the geotechnical parameters of the system. They are controlling a variety of factors such as the rate of the toe erosion, 
the critical shear strength, and style of failure, depth of the failing mass and the erodibility of the talus material which provides temporary protection of the cliff toe.

\subsection{Cliff Behaviour Unit (CBU)}

The difficulties in understanding the conditions and the processes that function on the cliffs, behind the cliffs as well as on the foreshore area, have led to the development of a conceptual model for cliff recession prediction. This concept is the "Cliff Behaviour Unit" and its purpose is to provide a "powerful tool for cliff management".

The Cliff Behaviour Units (CBUs) have been developed in order to bridge the nearshore processes with the cliff top processes and connect them with the neighbouring CBUs in a framework that is provided by the coastal process units. Cliffs are considered as open sediment transport systems that consist of inputs, throughputs and outputs of material (Lee and Clark, 2002). The development of the evolution model is founded on geomorphological, geotechnical and historical evidences and data. These evidences and data provide the basis for understanding past and recent behaviours of the cliff units. Furthermore, a variety of characteristic CBUs have been developed and divided in four main categories according to their complexity, type of failure and storage of sediments within the system (Lee and Clark, 2002). These are: a) simple cliffs, b) composite cliffs, c) Complex cliffs, d) relict cliffs.

\section{Case study}

\subsection{Introduction}

The project area is located in South West England in the county of Dorset. More specifically, it is located at the eastern end of the Isle of Purbeck in the peninsula between Swanage Bay and Studland Bay and consists mainly of chalk cliffs. This site has been chosen due to the variety of failure mechanisms that are present in a very narrow area. Furthermore, no human activities have taken place in the site that could alter the recession cycle.

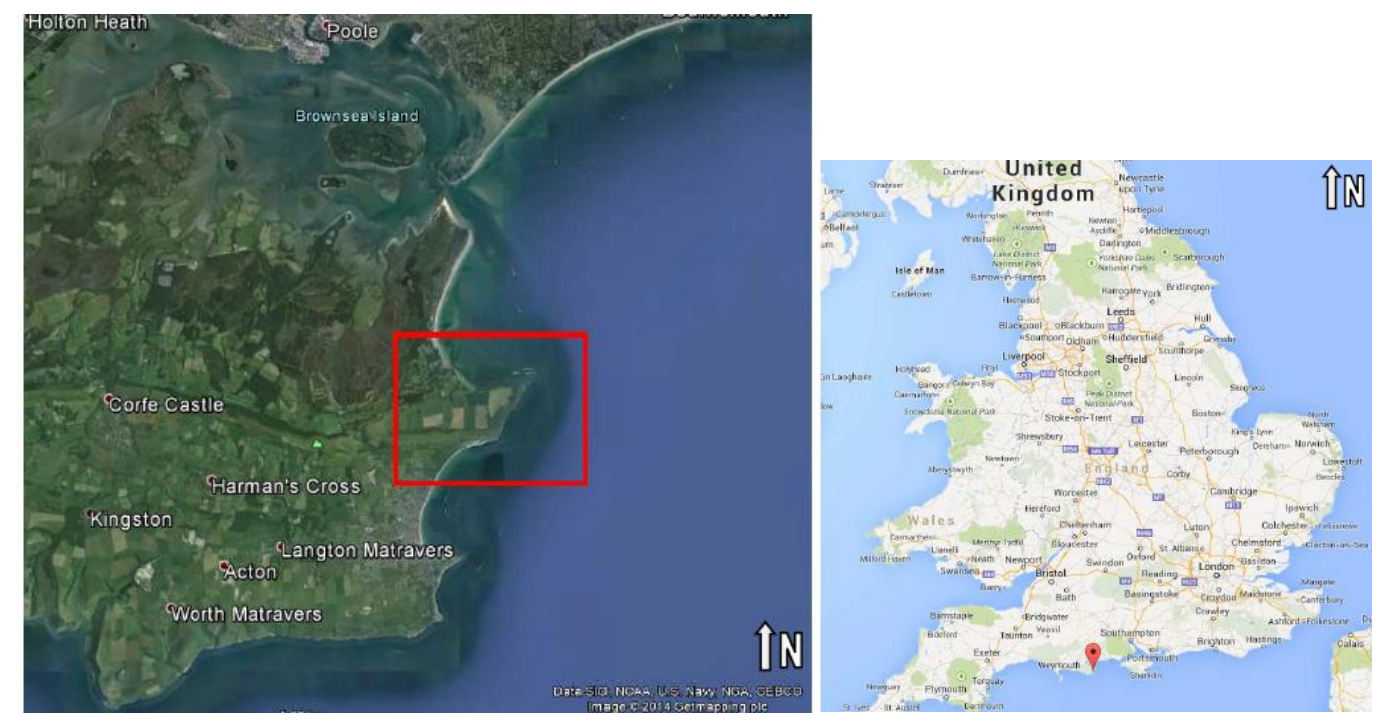

Figure 2 - Isle of Purbeck - Case study area (Google Earth, 2014).

The site is part of World Heritage Site as declared by UNESCO in 2001. The activities in the area of Dorset are mainly agricultural, touristic, mineral and petroleum extraction (Barton et al., 2011). 


\subsection{Geology}

The area of Dorset has been affected by several different events and sediments had been deposited in a variety of environments. The investigation of the geological history of the region led to a better understanding of the processes that are taking place nowadays and how the geology and the tectonic settings of the area affect the type of failure. Nowadays, the major processes that are affecting the area of Dorset are soil erosion, alluvium deposits, coastal erosion and cliff recession (Barton et al., 2011).

According to Mortimore et al. (2001) the section of Chalk cliffs between Swanage and Studland can be divided in three parts. This peninsula was formed by the sea erosion which broke the narrow Chalk ridge that connected this area with the Isle of Wight.

The first section outspreads from Swanage Bay until Ballard Point. This section exposes the sequence between the contact of Chalk Group and Upper Greensand until the lower part of Lewes Nodular Chalk Formation. The upper Lewes Nodular Chalk Formation is forming the Headlands and its thickness is about $13 \mathrm{~m}$. Furthermore, the Grey Chalk Subgroup (Zig Zag Formation) rests in this area on a glauconitic Basement Bed. The second section extends from Ballard Point until Old Harry Rocks. It consists of Geological Conservation Review sites and includes the Ballard Point Fault and the Upper Campanian section. The last section is extended from Old Harry Rocks to Studland Bay and consists of the Studland Chalk and Palaeogene deposits (Mortimore et al., 2001).

The most important structure that is exposed on the east side of the cliffs is the Ballard Point or Ballard Down Fault. The plane of the fault forms a curve and dips parallel to the Upper Cretaceous Chalk. The rock mass has been subjected to large tectonic deformation which developed thrust faults in the mass of the chalk. In addition, the peninsula constitutes part of a monocline structure and it is located very close to the Purbeck fault. Furthermore, unmapped minor faults should be expected in the chalk which will affect the discontinuity frequency. Based on this it is evident that the frequency and spacing of discontinuities will be affected from the past tectonic activity, resulting in an irregular pattern which controls the type of cliff failure.

\subsection{Geotechnical conditions of chalk}

The most common classification for the chalk is based on density and porosity. Although, some doubts have been expressed, the measurement of the density is the simpler way to describe intact material (Warren and Mortimore, 2003). Chalk is considered as a homogeneous material but in reality is a very complex sedimentary formation with various physical properties. Furthermore, the complex nature of the material is derived from processes like bioturbation, diagenesis, sendimentation and the region's structural history (Mortimore et al., 2004; Duperret et al., 2005).

Mortimore et al. (2004) conducted a series of different experiments in order to establish a reliable classification of chalk. Generally, they determine a reduction of strength (angle of friction and cohesion) as the degree of saturation increases. The critical role of the water contained either in the pores or the fissures in the stability of chalk cliffs was confirmed (Mortimore et al., 2004).

\section{Cliff instability}

\subsection{Introduction}

The study area was divided in three sections based on the type of cliff failure and the cliff behaviour unit approach, as shown in Figure 3. The first section is facing north and located in the Studland Bay. The rates of erosion in this area are lower because the cliffs are not susceptible to great wave energy due to their orientation. Moreover, the existence of shore platform in front of the cliffs is reducing the wave energy. Also, the wave energy had produced, in some cases, under-cutting or over-steepening of the cliffs' toe. 
The second section is facing east, towards the Isle of Wight. In this area, the rates of erosion are expected to be greater. In various cases, the existence of notch as well as structurally controlled failures has been observed. The third section is facing south and located in the Swanage Bay. A completely different type of failure is taking place in this area, mainly due to different bedding orientation (vertical) and the lower quality of the rock mass. The instability conditions of sections 1 and 3 are presented in the next paragraphs.

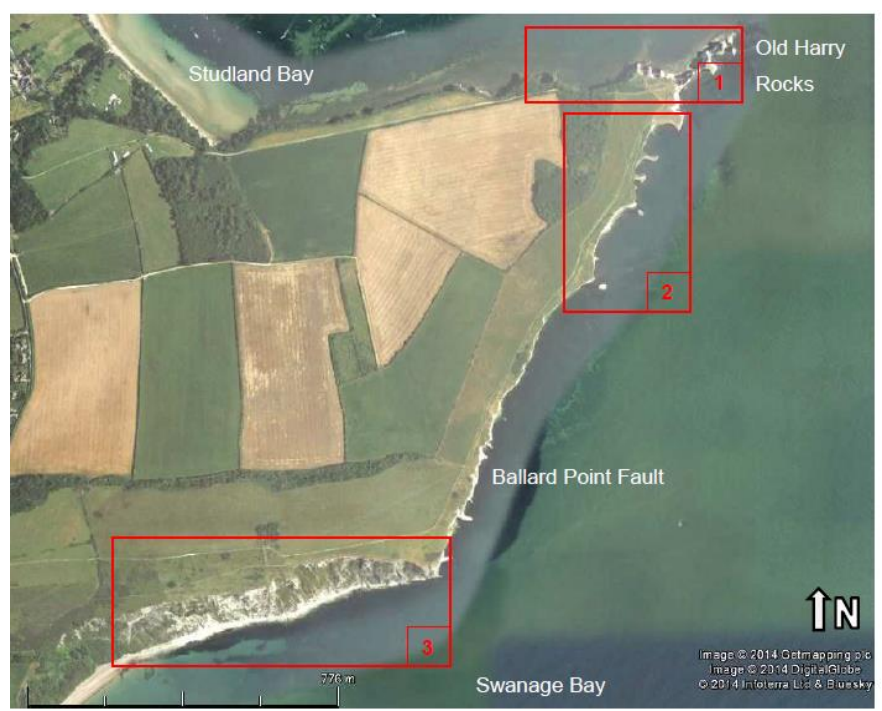

Figure 3 - Study area divided in 3 sections based on the Cliff Behaviour Unit approach.

\subsection{Cliff instability conditions}

\subsubsection{Section 1}

The bedding in section 1 is near-horizontal $\left(8^{\circ}\right)$ and dips towards North. The height of the cliffs has a range between $15 \mathrm{~m}$ and $20 \mathrm{~m}$. The chalk can be possibly divided in two subunits.

The border line between these units is most of the times a yellow band parallel to the bedding. The pattern of the fractures in the upper part is very dense and creates blocks of a rectangular or even triangular shape. The bedding is thinner than the bedding in the lower part. The lower part has not only thicker bedding, but the rock mass is also less fractured. Furthermore, the yellow band was used in almost all cases as a reference bed. The conditions are summarised as follows:

- The shore platform and the orientation of the Studland Bay reduce the wave energy.

- Fronting beach is protecting the cliffs.

- Clear evidence of notch formation on the right side of the photo. The rate of notch formation cannot be calculated.

- Very weathered upper part of chalk. Thinner bedded.

- Minor instabilities in the upper part of the Chalk. Joint controlled failures.

- Generally stable. Phase 1 of the recession cycle.

- Increase of vegetation height and surface area, shows stable conditions.

In terms of CBU, this section is characterised as "simplified cliff - topples and falls". In specific sites, it was observed that the failures follow a characteristic and repeatable type of failure. In order to determine the retreat rates of the section, a longer observation period was necessary as whole cycles of recession need to be observed. 

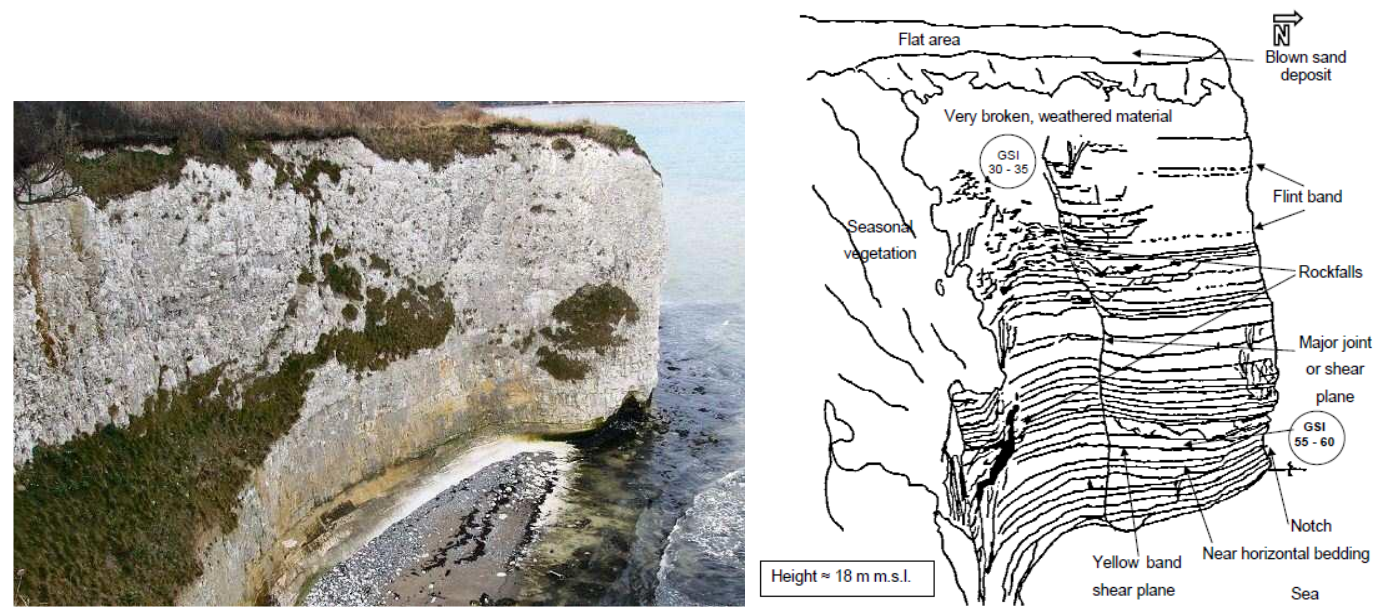

Figure 4 - Section 1, a) photo b) cliff stability block chart.

\subsubsection{Section 3}

The bedding in this section is almost vertical. The height of the cliffs ranges between $80 \mathrm{~m}$ to $110 \mathrm{~m}$. The type of failure is different from that in the other two sections. The main reasons are the different orientation of the bedding, the lower quality of the rock mass and the orientation of the site against wave action. Three different types of failure have been identified. In some cases, more than one failure mechanism was identified in one cliff instability. For example, a failure starts as a single rock fall and consequently destabilises a bigger mass, which is underneath, and causes debris fall involving larger rock mass. In this area, the triggering factors are mainly the low quality of the rock mass and the vertical bedding, the wave energy and the extreme weather events.

A general ground model of section 3 is presented in Figure 5, illustrating the various geomorphological features, the mechanisms and types of cliff instability in this area.

The conditions in characteristic points ( 1 to 4 in Figure 5 ) along the cliff are described. In point 1 they are summarised as follows:

- High rates of retreat. Significant changes in 5 years.

- No protection from wave energy. Generally unstable.

- Phase 1 of the recession cycle on the left: Under - cutting.

- Phase 4 of the recession cycle on the right: Debris removal

- Structurally controlled instabilities

- Height from the sea level $\approx 90 \mathrm{~m}$

- Seasonal vegetation shows only temporary stability

In point 4 they are summarised as follows:

- High rates of retreat. No protection from wave energy.

- Rotational landslide. Unstable due to constant toe undercutting.

- Constant instabilities. Rock falls and under-cutting of the failed mass.

- Phase 4 of the recession cycle on the right: Debris removal.

- Structural controlled instabilities in the upper part of the slope.

- Height from the sea level $\approx 100 \mathrm{~m}$.

- Seasonal vegetation shows only temporary stability. 
Section 3 was divided in three sub-sections (Figure 5) according to the type of failure that has been observed. The first sub-section is located in the western part and consists of a large rotational landslide. Close to the toe of the landslide, some remaining features of and older and smaller landslide can be identified. This area is slowly eroded by wave action and can be characterised as an earlier stage of the sub-section 2 (middle part). The main triggering factors are the under-cutting of the toe of the landslide due to wave erosion, the freeze-thaw action and the wind erosion. In terms of recession cycle it can be identified that the sub-section 1 is at the last stage (debris removal).

The second sub-section consists of multiple debris fans at the lower part of the slope. Some of these fans are probably the remaining part of older landslides. In terms of recession cycle, the events in sub-section 2 are similar to the one of subsection 1 but less intense. This is probably due to the fact that sub-section 2 is a later stage of sub-section 1 and the volume of the fallen material is lower.
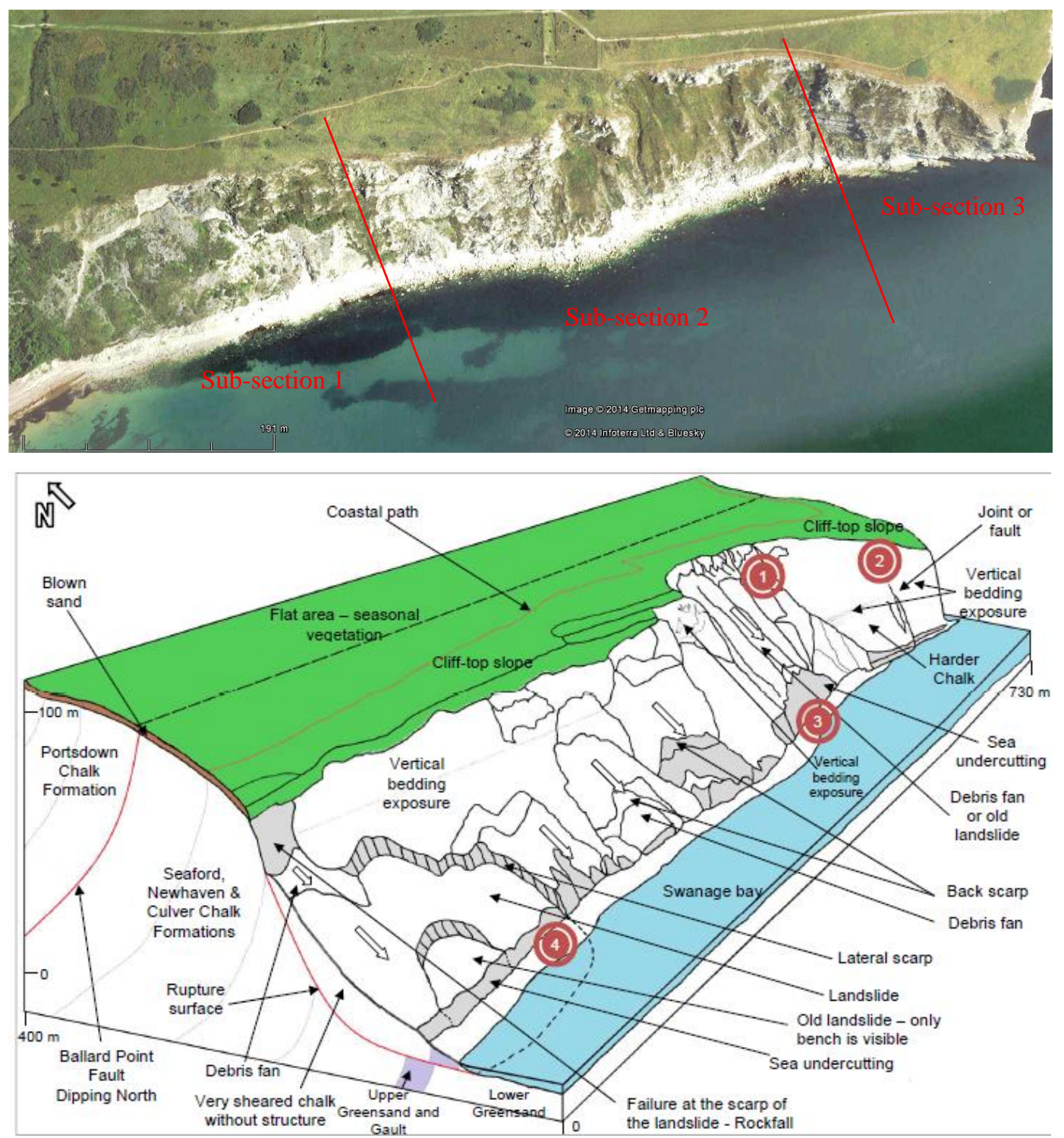

Figure 5 - Section 3, a) photo b) cliff stability ground model (block chart). 
The last sub-section is situated at the eastern part of the section 3. In this section the vertical bedding of the Chalk is outcropping and forms almost vertical cliffs approximately $70 \mathrm{~m}$ high. In this subsection the Chalk has higher quality than in the other two sections. The rates of retreat are also significantly lower and only topple failures and small debris falls have been identified.

In terms of CBU, the first and second sub-section are characterised as "complex cliffs, deep-seated landslide with failure at more than one level". The third sub-section, which has similar types of failures, is identified in the category "simple cliffs". Moreover, in this section, a long period of observation would be beneficial. The data from a longer period of observation can add information for the type of failure, the number of the events, the rate of over-steepening formation and erodibility of the debris. This information will give more data for the recession cycle and the period of the cycle, as well as the retreat rates.

\section{Discussion}

The coastal cliff which was studied was found ideal for the observation of different mechanisms of cliff instability. It also demonstrates clearly the cliff behaviour unit approach and its importance in the determination of the retreat of coastal cliffs.

All the failures in the selected site were found to be related with natural processes only as there is no human activity in the area. The outcome of this work should be compared only to sites, where no coastal protection works have been constructed along the coastline and were similar quality of rocks mass exists (in terms of rock strength and frequency of fracturing).

It was found difficult to calculate accurately the rate of cliff retreat in the study areas. The rates have been calculated from historical. The need of accuracy in the calculation requires the use of good quality aerial photos. A preliminary assessment of cliff instability was performed and presented in Figure 6. The unstable areas are identified in red, while the stable areas in green colour. The areas that seemed stable during the site investigation but are categorised as areas of potential higher instability denoted in orange.

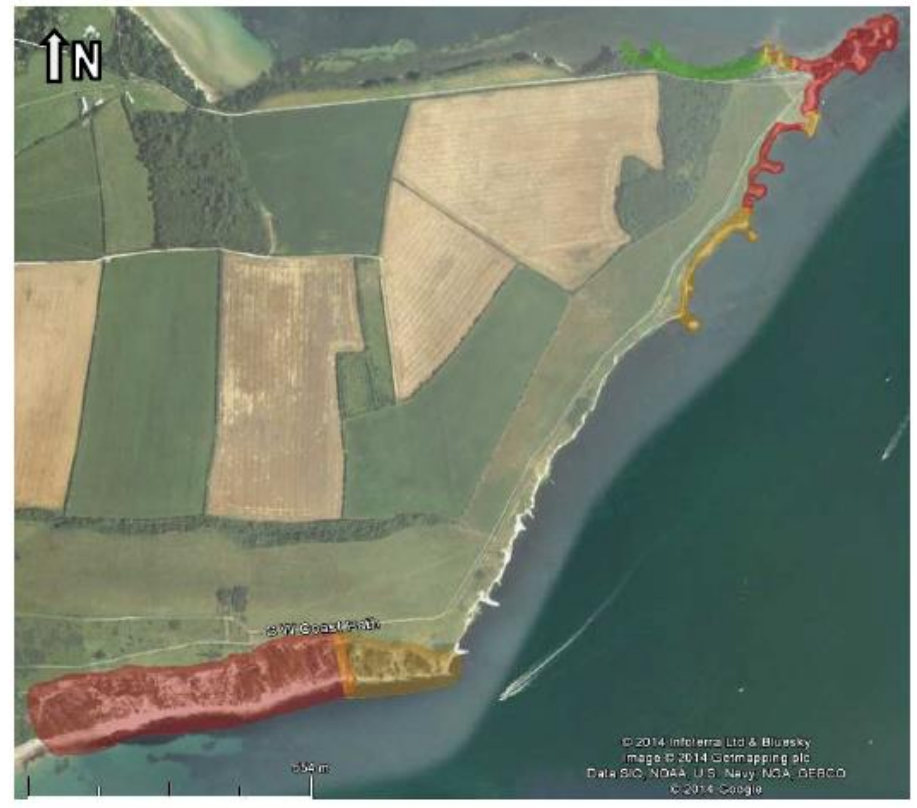

Figure 6 - Coastal cliff instability map. 


\section{References}

Adams, P.N., Anderson, R.S. and Revenaugh, J., 2002. Microseismic measurement of wave energy delivery to a rocky coast, Geology, 30(10), 895-898.

Allison, R.J. and Kimber, O.G., 1998. Modelling failure mechanisms to explain rock slope change along the Isle of Purbeck coast, UK, Earth Surface Processes and Landforms, 23(8), 731-750.

Barton, C., Woods, M., Bristow, C., Newell, A., Westhead, R., Evans, D., Kirby, G. and Warrington, G., 2011. Geology of south Dorset and south-east Devon and its World Heritage Coast: Special Memoir for 1: 50000 geological sheets 328 Dorchester, 341/342 West Fleet and Weymouth and 342/343 Swanage, and parts of sheets 326/340 Sidmouth, 327 Bridport, 329 Bournemouth and 339 Newton Abbot. British Geological Survey.

British Geological Survey Coastal Erosion team, 2012. UK Geohazards note. Available from: http://www.bgs.ac.uk/research/climatechange/environment/coastal/home.html.

Carpenter, N., 2014. Development of an Integrated Soft Cliff Model to Determine the Impacts of Environmental and Climatic Change on Coastal Recession, Ph.D Thesis, University of Southampton.

Castedo, R., Murphy, W., Lawrence, J. and Paredes, C., 2012. A new process-response coastal recession model of soft rock cliffs, Geomorphology, 177, 128-143.

Collins, B.D. and Sitar, N., 2008. Processes of coastal bluff erosion in weakly lithified sands, Pacifica, California, USA, Geomorphology, 97(3), 483-501.

Duperret, A., Taibi, S., Mortimore, R.N. and Daigneault, M., 2005. Effect of groundwater and sea weathering cycles on the strength of chalk rock from unstable coastal cliffs of NW France, Engineering Geology, 78(3), 321-343.

Emery, K. and Kuhn, G., 1982. Sea cliffs: their processes, profiles, and classification, Geological Society of America Bulletin, 93(7), 644-654.

Lee, E., Hall, J. and Meadowcroft, I., 2001. Coastal cliff recession: the use of probabilistic prediction methods, Geomorphology, 40(3), 253-269.

Lee, E.M. and Clark, A.R., 2002. Investigation and management of soft rock cliffs, Thomas Telford.

Limber, P.W. and Murray, A.B., 2011. Beach and sea-cliff dynamics as a driver of long-term rocky coastline evolution and stability, Geology, 39(12), 1147-1150.

Moore, R., Rogers, J., Woodget, A. and Baptiste, A., 2010. Climate change impact on cliff instability and erosion, Environment Agency Annual Conference, (FCRM), 079.1.

Mortimore, R.N., Wood, C.J. and Gallois, R.W., 2001. British upper cretaceous stratigraphy, Joint Nature Conservation Committee (JNCC).

Mortimore, R., Stone, K., Lawrence, J. and Duperret, A., 2004. Chalk physical properties and cliff instability.

Rosser, N.J., Brain, M.J., Petley, D.N., Lim, M. and Norman, E.C., 2013. Coastline retreat via progressive failure of rocky coastal cliffs, Geology, 41(8), 939-942.

Small, C. and Nicholls, R.J., 2003. A global analysis of human settlement in coastal zones, Journal of Coastal Research, 584-599.

Sunamura, T., 1982. A wave tank experiment on the erosional mechanism at a cliff base, Earth Surface Processes and Landforms, 7(4), 333-343. 